\title{
Vertebral Arteriovenous Fistulae (AVF) in Neurofibromatosis Type 1: A Report of Two Cases
}

\author{
Nörofibromatosis Tip 1'de Vertebral Arteriyovenöz Fistül (AVF): \\ İki Olgu Sunumu
}

\author{
Peng GAO ${ }^{1}$, Yanfei $\mathrm{CHEN}^{1}$, Hongqi ZHANG ${ }^{1}$, Peng ZHANG ${ }^{2}$, Feng LING ${ }^{1}$ \\ ${ }_{1}^{1}$ Xuanwu Hospital, Capital University of Medical Sciences, Department of Neurosurgery, Beijing, P.R. China \\ ${ }^{2}$ Xuanwu Hospital, Capital University of Medical Sciences, Interventional Diagnosis and Treatment Center, Beijing, P.R. China
}

Correspondence address: Feng LING / E-mail: lingfengdoc@yahoo.com.cn

\begin{abstract}
Spontaneous vertebral arteriovenous fistulae (AVF) associated with neurofibromatosis Type 1 (NF-1) is a rare occurrence in the previous reports. We presented two female NF-1 patients with a diagnosis of cervical vertebral AVF treated with endovascular approach. The fistula in the first case was successfully obliterated by feeder occlusion; whereas, for the second one, new fistulae were formed following the primary fistula closure. Anatomic and hemodynamic changes in combination with dysplastic vascular condition in NF-1 may contribute to fistulae formation de novo. The present case points out a rare challenge encountered in the treatment of vertebral arteriovenous fistula complicated by previous fistula obliteration in NF-1.
\end{abstract}

KEYWORDS: Interventional neuroradiology, Neurofibromatosis Type 1, Vertebral arteriovenous fistula

öz

Nörofibromatosis Tip 1 (NF-1) ile ilişkili spontan vertebral anteriyovenöz fistül (AVF) önceki raporlarda nadiren bildirilmiştir. Endovasküler yaklaşımla tedavi edilen servikal vertebral AVF tanısına sahip iki kadın NF-1 hastası sunuyoruz. İlk vakadaki fistül besleyici damar oklüzyonuyla başarılı şekilde oblitere edilirken ikinci vakada primer fistül kapatıldığnda yeni fistüller oluştu. NF-1'de displastik vasküler durumla kombinasyon halinde anatomik ve hemodinamik değişiklikler de novo fistül oluşumuna katkıda bulunabilir. Mevcut vaka NF-1'de önceki fistül obliterasyonu komplikasyonu bulunan vertebral arteriyovenöz fistül tedavisinde karşılaşılan nadir zorluklara işaret etmektedir.

ANAHTAR SÖZCÜKLER: Girişimsel nöroradyoloji, Nörofibromatosis Tip 1, Vertebral arteriyovenöz fistül

\section{INTRODUCTION}

Neurofibromatosis-1 (NF-1) is an autosomal dominant inheritant disease with generalized neuroectodermal and mesodermal dysplasia that affects the skin, nervous system, skeleton and vascular system. Spontaneous arteriovenous fistulae (AVF) of the vertebral artery in NF-1 have been rarely described $(3,8-9)$. We presented two cases, and its potential pathogenesis was discussed.

\section{CASE REPORTS}

\section{Case 1}

A 24-year-old woman complained progressive cervical pain for 3 months after a baby delivery. Physical examination demonstrated numerous café-au-lait spots in the skin (Figure $1 \mathrm{~A}$ ) and palpable thrill over the right neck. Diagnostic angiography defined the vascular anatomy as a vertebral AVF at C2-3 level (Figure 2A, B). Left VA angiogram demonstrated retrograde flow in right VA, suggesting steal flow (Figure $2 \mathrm{C}$, $D)$. The fistula was fed by proximal antegrade in right VA and distal retrograde flow in left VA. The flow joined together into the same varix. Therefore, the intervention strategy was to occlude the feeding arteries and varix. Multidisciplinary modalities were used. After systemic heparinization, right and left vertebral arteries were catheterized with an $8 \mathrm{~F}$ and $6 \mathrm{~F}$ guiding catheter, respectively. Two Echelon-10 microcatheters over a SilverSpeed 0.010-in microguidewire (eV3) were advanced via right and left vertebral approach to reach the varix, respectively. A detachable balloon (GOLDBAL2, $7 * 20 \mathrm{~mm}$, BALT EXTRUSION) was placed via $8 \mathrm{~F}$ guiding into the varix to provide flow control, which allowed us to deploy 3 coils altogether for the obliteration of varix $(\mathrm{Helix}, 10 * 30 \mathrm{~cm}$, eV3; GDC-18, 360 standard, $22 * 40 \mathrm{~cm} \times 2$, Boston Scientific). Appropriate mixture of glue (Onyx-HD-500, $1 \mathrm{ml}$; Onyx-34, $1 \mathrm{ml} ; \mathrm{eV} 3$ ) was used to avoid coils migration, and the fistula disappeared (Figure 2E-H). Neck pain was greatly relieved after intervention. She has been followed up for half a year, and there has been no complaint of neck pain.

\section{Case 2}

A 46-year-old woman presented with NF-1 and was referred for progressive neck mass and humming sound over right neck 


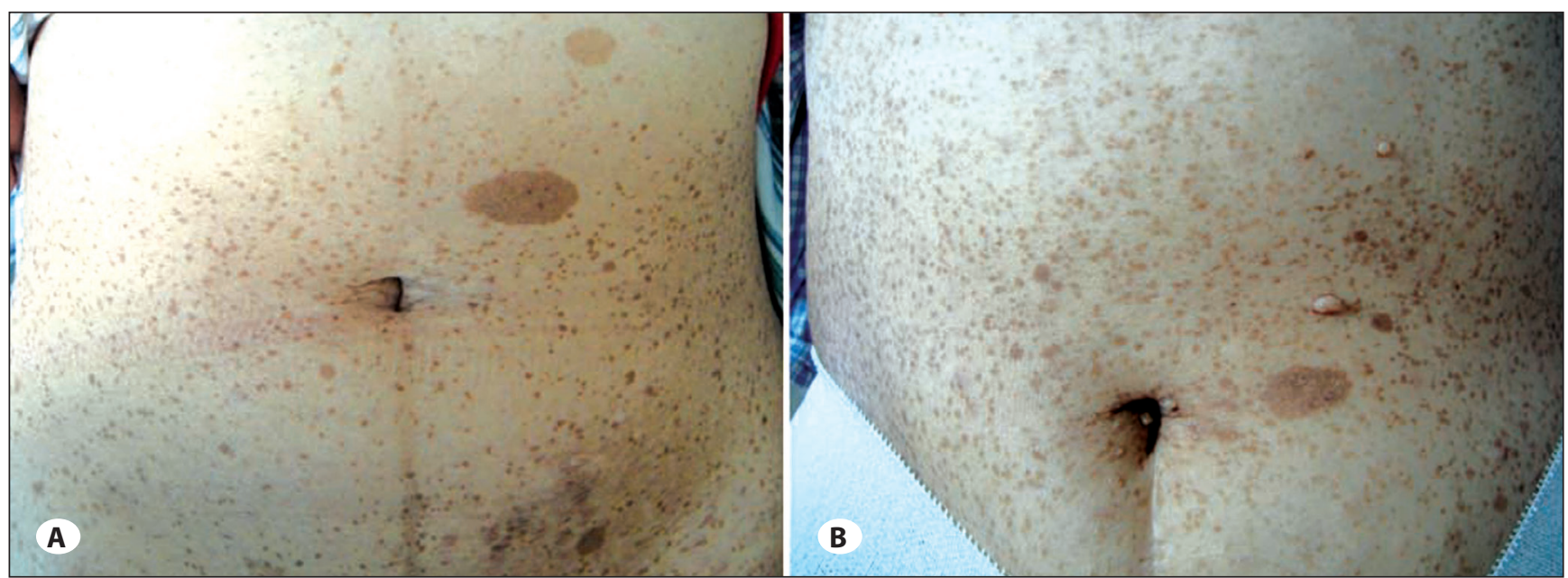

Figure 1: café-au-lait spots and sub-cutaneous neurofibroma in the abdominal skin (A, case 1; $\mathbf{B}$, case 2).

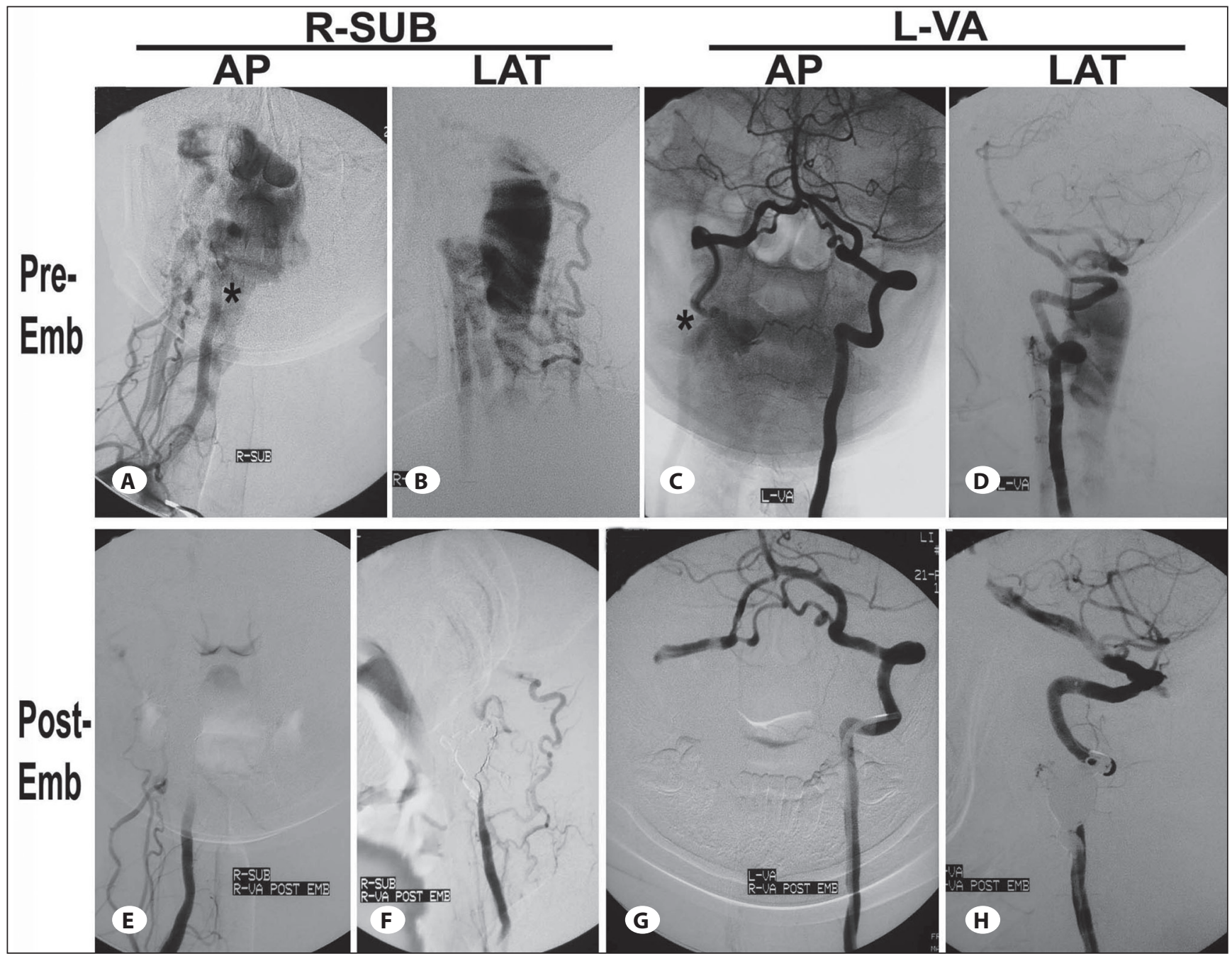

Figure 2: Case 1, embolization for the fistula. (A-D) Angiogram prior to treatment; $\mathbf{A}$ and B, R-SUB angiogram, the dilated draining vein and the fistula site could be directly observed; $\mathbf{C}$ and $\mathbf{D}$, left vertebral angiogram, showed retrograde flow due to the sump effect, suggesting steal flow. The proximal and distal entry of the feeding artery was indicated as asterisks $\left(^{*}\right)$. (E-H) Angiogram after treatment: proximal (E-F) and distal (G-H) entry of the feeder as well as the varix were successfully obliterated with coiling and glue embolization. AP, antero-posterior view; LAT, lateral view; SUB, sub-clavicle artery; VA, vertebral artery; EMB, embolization. 


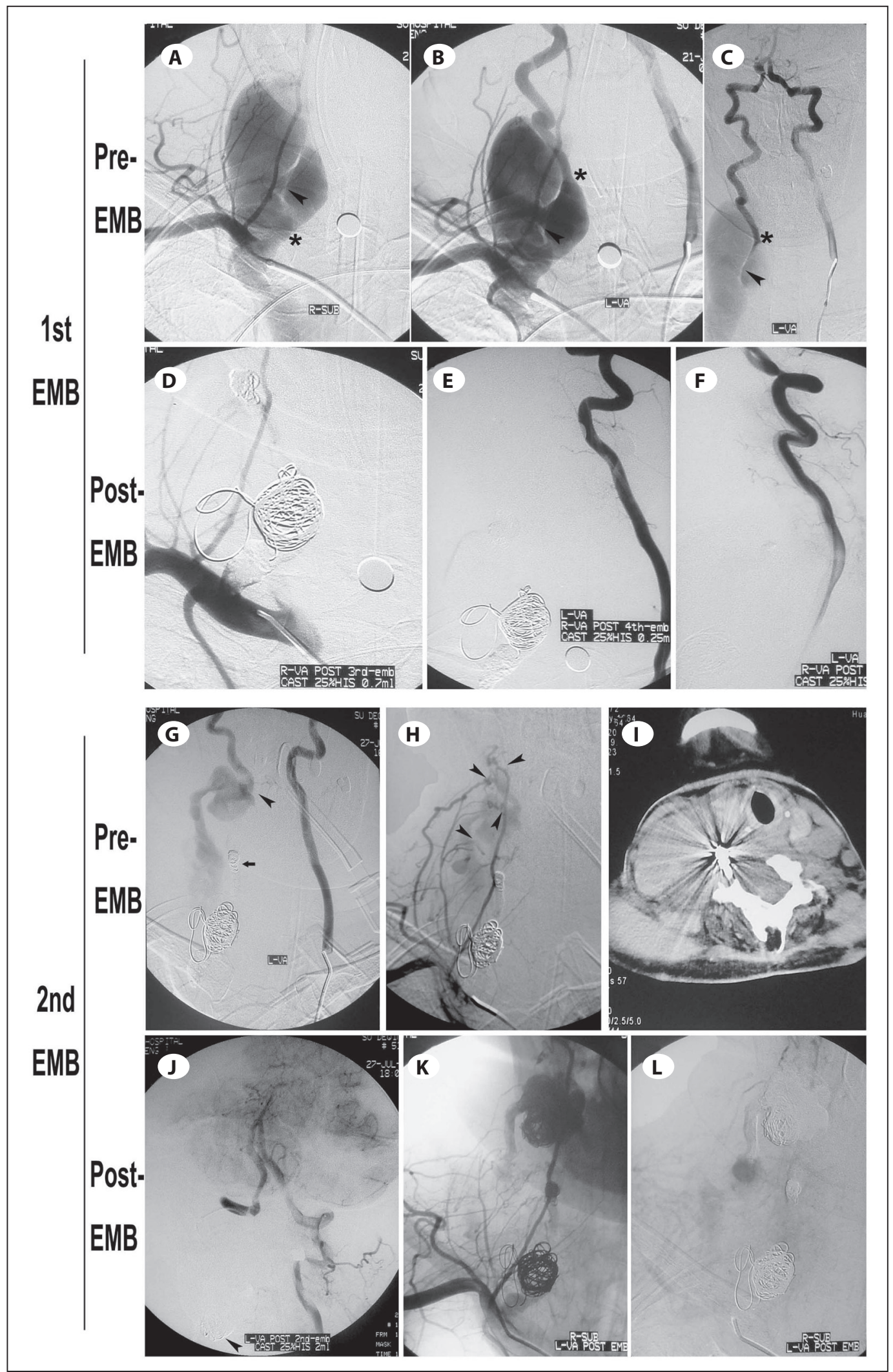

Figure 3: Case 2, embolization for the fistula. (A-C) Angiogram prior to $1^{\text {st }}$ treatment; right (A) and left VA (B and C) angiogram showed an AVF between right VA and internal jugular vein. Fistula was noted by arrowhead; B and C, left VA angiogram, showed retrograde flow due to the sump effect, suggesting steal flow. The proximal and distal entry of the feeding artery was indicated as asterisks (*). (D-F) Angiogram after $1^{\text {st }}$ treatment; the proximal (D) and distal (E-F) entry of the feeder as well as the varix were successfully obliterated with coiling and glue embolization. (G-I) Angiogram prior $2^{\text {nd }}$ treatment; $\mathbf{G}$, left VA angiogram showed a new fistula (arrow) formed distal to the previous one (dark arrow); $\mathbf{H}$, left SUB angiogram showed multiple collateral from cervical arteries contributing to the fistulae de novo and venous pouch (arrows); I, trachea was not severely displaced on CT scan. (J-L) Angiogram after $2^{\text {nd }}$ treatment; J, left VA arteriogram confirmed successful occlusion of the new fistula (arrow); $\mathbf{G}$ and $\mathbf{H}$, numerous tiny fistulae still open after new fistula closure. 
for over 15 years. Neurofibromatosis-1 (NF-1) was diagnosed at age of 20 on the basis of pathological examination. Physical examination demonstrated numerous sub-cutaneous neurofibroma, café-au-lait spots in the skin (Figure 1B), a palpable thrill, and a prominent systolic bruit over the mass. Angiography defined the vascular anatomy as a vertebral fistula at the C5 level (Figure 3A, B). The feeder directly communicated with the internal jugular vein, manifesting as an extensive pulsate mass. Left VA angiogram demonstrated retrograde flow, suggesting steal flow (Figure $3 \mathrm{C}$ ). The carotid arteries and intracranial circulation were normal.

\section{$1^{\text {ST EMBOLIZATION }}$}

Case 2 shared the same vascular anatomy as case 1, so the same intervention strategy was used. After systemic heparinization, two Echelon 10 microcatheters over a SilverSpeed 0.010-in microguidewire (eV3) were advanced at right and left VA close to fistula point, respectively. A remodeling balloon (Hyperform, $7 \mathrm{~mm}^{*} 7 \mathrm{~mm}, \mathrm{eV} 3$ ) was placed to provide flow control via right $V A$ approach. The balloon was inflated, which allowed us to deploy 4 Microplex coils for distal feeder obliteration and 5 Microplex coils for proximal feeder obliteration. Appropriate mixture of glue was applied to the previous coils for protective embolization (GLUBRAN 2 acrylic glue). The fistula was not opacified (Figure 3D-F).

\section{$2^{\text {ND }}$ EMBOLIZATION}

Four days after fistula closure, this patient complained of sudden neck pain associated with an extensive subcutaneous mass. The even larger lesion compressed the brachial plexus and caused weakness in the right upper extremity. Cervical CT showed trachea was not severely displaced laterally (Figure 3I). Angiography disclosed that a new fistula, distal to the previous one, was formed between right VA and the paravertebral venous plexus at the C2 level (Figure 3G).

A flow-directed microcatheter over a 0.008-in microguidewire (eV3) was navigated distally to the new fistula across the vertebrobasilar junction via left VA route. Four coils were deployed, and adjunct glue (GLUBRAN 2 acrylic glue) was used via left VA approach for the new fistula closure (Figure 3J-L). Right Sub angiogram disclosed a complex AVF, with numerous collateral flows contributing to the same varix. Those flows arose from muscular branches of thyrocervical and costocervical trunk (Figure 3H). Treatment was complicated and total obliteration was impossible. Postoperative examination demonstrated a significant decrease in size of mass, with relief of the compression of the brachial plexus. She has been followed up for half a year, and there has been no complaint of discomfort.

\section{DISCUSSION}

There have been only 40 cases of AVF in 37 reports associated with NF-1 in the previous literature since 1946. Most of them (84\%) were vertebral AVF. The majority of patients are female. Koenigsberg (7) and Cluzel et al (3) have listed a literature review of previous publications.
Vertebral fistulae have a unique predilection to develop in NF-1 patients. The pathogenesis of AVF associated with NF-1 has not been determined, but it is believed that fragility and defects of the arterial wall related to NF-1 might be a predisposing factor. As early as 1982, Deans et al (4) proposed two possible mechanisms by which an AVF might arise in patients with NF-1: vascular sequelae presented as abnormalities of connective tissue, including dysplastic smooth muscle in the arterial wall. This resulted in vessel vulnerability, and friability (11). Alternatively, the abnormal arteriovenous communications are primarily congenital in nature (8) and arise directly as a manifestation of mesodermal dysplasia association with NF-1 $(4,5)$ among young patients (4).

The $2^{\text {nd }}$ case might demonstrate both of the mechanisms above. The occlusion of the previous fistula probably resulted in flow redistribution, and abnormal flow in parent artery. This allowed for the development of collaterals and made the congenital fistulae open. Microvascular and anatomic in combination with hemodynamic changes could lead to mural weakening, leakage, perforation, and ultimately rupture into adjacent vein, resulting in the formation of new fistulae de novo and huge varix after shunt.

Surgical strategy is aimed at complete feeder occlusion. Vascular fragility associated with NF-1 created difficulties for open surgery, and sometimes even life-threatening bleeding made surgery impossible (14). Endovascular intervention was favorable (2), and the entry zone of the feeder was selected as the appropriate occlusion point.

The fistulae were of high flow in the current two cases; coiling of the fistulous sac in parent VA plus a remodeling balloon technique was preferred because it allows for better flow control (10), coils deployment and fistula closure. Liquid embolic agent adjunct embolization may minimize risk of coils migration into the venous side $(1,6,13)$. Occlusion was achieved through an antegrade and retrograde approach (12) using coils, balloons combined with glues. Mass effect, such as brachial plexus compression, decreased postoperatively.

Due to the vascular dysplastic condition in NF-1 patients, the two cases, the $2^{\text {nd }}$ one in particularly, points out a rare challenge encountered in the treatment of vertebral fistula complicated by previous fistula closure. It highlighted that great care should be taken to avoid any iatrogenic damage to the vessels during the intervention.

\section{GRANT INFORMATION/OTHER ACKNOWLEDGMENTS}

This study was supported by National Natural Science Foundation of China (81200910).

\section{FINANCIAL DISCLOSURE}

We have no conflict of interest to disclose. 


\section{REFERENCES}

1. Andreou A, loannidis I, Nasis N: Transarterial balloon-assisted glue embolization of high-flow arteriovenous fistulas. Neuroradiology 50:267-272, 2008

2. Anegawa S, Hayashi T, Torigoe R, Iwaisako K, Sakae N, Ogasawara T, Utsunomiya $\mathrm{H}$ : Symptomatic arteriovenous fistula in a patient with neurofibromatosis type I. No Shinkei Geka 25:373-378, 1997

3. Cluzel P, Pierot L, Leung A, Gaston A, Kieffer E, Chiras J: Vertebral arteriovenous fistulae in neurofibromatosis: Report of two cases and review of the literature. Neuroradiology 36:321-325, 1994

4. Deans WR, Bloch S, Leibrock L, Berman BM, Skultety FM: Arteriovenous fistula in patients with neurofibromatosis. Radiology 144:103-107, 1982

5. Greene JF Jr, Fitzwater JE, Burgess J: Arterial lesions associated with neurofibromatosis. Am J Clin Pathol 62:481-487, 1974

6. Guedin P, Gaillard S, Boulin A, Condette-Auliac S, Bourdain F, Guieu S, Dupuy M, Rodesch G: Therapeutic management of intracranial dural arteriovenous shunts with leptomeningeal venous drainage: Report of 53 consecutive patients with emphasis on transarterial embolization with acrylic glue. J Neurosurg 112:603-610, 2010

7. Koenigsberg RA, Aletich V, Debrun G, Camras LR, Ausman Jl: Cervical vertebral arteriovenous fistula balloon embolization in a patient with neurofibromatosis type 1. Surg Neurol 47:265-273, 1997
8. Kubota T, Nakai H, Tanaka T, Maeda T, Takano K, Tsuda N, Izumi N, Ogata N, Goto K: A case of intracranial arteriovenous fistula in an infant with neurofibromatosis type 1. Childs Nerv Syst 18:166-170, 2002

9. Parkinson D, Hay R: Neurofibromatosis. Surg Neurol 25: 109-113, 1986

10. Patro SN, Gupta AK, Arvinda HR, Jolapara MB, Saini J: Combined transarterial and percutaneous coiling of a spontaneous vertebrovertebral fistula associated with neurofibromatosis Type 1. Case report. J Neurosurg 111:3740, 2009

11. Schievink WI, Piepgras DG: Cervical vertebral artery aneurysms and arteriovenous fistulae in neurofibromatosis type 1: Case reports. Neurosurgery 29:760-765, 1991

12. Taylor CG, Husami Y, Colquhoun IR, Byrne JV: Direct cervical vertebro-venous fistula with radiculopathy and MRI changes resolving after successful endovascular embolisation: A report of two cases. Neuroradiology 43:1118-1122, 2001

13. Troffkin NA, Given CA, 2nd: Combined transarterial N-butyl cyanoacrylate and coil embolization of direct carotidcavernous fistulas. Report of two cases. J Neurosurg 106: 903-906, 2007

14. Westacott S, Mohan D, Norman PF, Strachan WE, Paxton RM: MRI diagnosis of vertebral arteriovenous malformations in neurofibromatosis. Br J Neurosurg 2:385-389, 1988 